\title{
Enforced expression of KDR receptor promotes proliferation, survival and megakaryocytic differentiation of TF1 progenitor cell line
}

\author{
S Coppola ${ }^{1}$, L Narciso ${ }^{1}$, T Feccia ${ }^{1}$, D Bonci ${ }^{1}$, L Calabrò ${ }^{1}$, \\ O Morsilli ${ }^{1}, M^{1}$ Gabbianelli ${ }^{1}$, R De Maria ${ }^{1}$, U Testa ${ }^{1}$ and \\ C Peschle*,1,2 \\ ${ }^{1}$ Department of Hematology, Oncology and Molecular Medicine, Istituto \\ Superiore di Sanità, Rome, Italy \\ 2 Kimmel Cancer Center Institute, Thomas Jefferson University, Philadelphia, \\ PA, USA \\ * Corresponding author: C Peschle, Kimmel Cancer Center Institute, Thomas \\ Jefferson University, Bluemle Life Sciences Building, Room 609, 233 South \\ 10th St., Philadelphia, PA 19107-5541, USA. Tel: + 1215503 4570; \\ Fax: + 1215923 0249; E-mail: cesare.peschle@ mail.tju.edu
}

Received 22.11.04; revised 11.4.05; accepted 09.5.05; published online 17.6.05 Edited by JP Medema

\begin{abstract}
Vascular endothelial growth factor (VEGF) receptor-2/kinase insert domain-containing receptor (KDR) is expressed in primitive hematopoietic cells, in megakaryocytes and platelets. In primitive hematopoiesis KDR mediates cell survival via autocrine VEGF, while its effect on cell growth and differentiation has not been elucidated. We induced enforced KDR expression in the granulocyte macrophage-colonystimulating factor (GM-CSF)-dependent TF1 progenitor cell line (TF1-KDR), treated the cells with VEGF and analyzed their response. In GM-CSF-deprived cells, VEGF induces cell proliferation and protection against apoptosis, followed by enhanced expression of megakaryocytic (MK) markers. Combined with GM-CSF, VEGF induces a mild proliferative stimulus, followed by cell adherence, accumulation in G0/G1, massive MK differentiation and Fas-mediated apoptosis. Accordingly, we observed that MK-differentiating cells, derived from hematopoietic progenitors, produce VEGF, express KDR, inhibition of which reduces MK differentiation, indicating a key role of KDR in megakaryopoiesis. In conclusion, TF1-KDR cells provide a reliable model to investigate the biochemical and molecular mechanisms underlying hematopoietic progenitor proliferation, survival and MK differentiation.

Cell Death and Differentiation (2006) 13, 61-74. doi:10.1038/sj.cdd.4401698; published online 17 June 2005
\end{abstract}

Keywords: KDR; megakaryocyte; VEGF; hematopoietic progenitor; proliferation

Abbreviations: CMV, cytomegalovirus promoter; GFP, green fluorescence protein; GM-CSF, granulocyte macrophage-colonystimulating factor; HPCs, hematopoietic progenitor cells; HSCs, hematopoietic stem cells; IRES, internal ribosomal entry site of encephalomyocarditis virus; KDR, kinase insert domain-containing receptor; MK, megakaryocytic; PMA, phorbol myristyl acetate; SC, stem cell; TPO, thrombopoietin; VEGF, vascular endothelial growth factor; VSV-G, vesicular stomatitis virus glycoprotein

\section{Introduction}

The vascular endothelial growth factor (VEGF) receptor-2 (VEGFR2/kinase insert domain-containing receptor (KDR)) is a tyrosine kinase receptor constitutively expressed in endothelial cells, which mediates proliferative, differentiation and survival signals through interaction with VEGF. ${ }^{1-4}$ Knockout studies demonstrated that KDR is necessary for the development of both endothelial and hematopoietic tissues. ${ }^{5}$ KDR-/- embryos show major defects in vasculogenesis and blood-island formation, suggesting a defect of the hemangioblast, that is, the stem cell (SC) for both hematopoietic and endothelial lineages. ${ }^{6} \mathrm{KDR}$ plays an essential role in regulating the migration of early mesodermal progenitors into the hematopoietic microenvironment (yolk sac, fetal liver). ${ }^{7}$ Recent studies further indicated that KDR promotes self-renewal and erythroid development of the human embryonic SC. ${ }^{8}$

In post-natal life, KDR is expressed in the hematopoietic system. Leukemic cells of the lymphoid and myeloid type may express KDR and produce VEGF, suggesting an autocrine loop in the control mechanisms of leukemia: ${ }^{9-13}$ in particular, KDR stimulation promotes migration, inhibits apoptosis and moderately enhances cell growth. In this regard, it is not elucidated whether the increase in leukemic cell growth is in part mediated by a proliferative stimulus, besides the apoptosis inhibition. ${ }^{14-16}$ In normal hematopoiesis, KDR is expressed in a subset of $\mathrm{CD} 34^{+}$cells. ${ }^{15,17,18}$ Specifically, KDR identifies not only endothelial precursors ${ }^{18}$ but also hematopoietic stem cells (HSCs) and primitive progenitor cells (HPCs).$^{17}$ Furthermore, postnatal $\mathrm{CD} 34^{+} \mathrm{KDR}^{+}$cells comprise hemangioblasts, endowed with bipotent hematopoietic and endothelial differentiation capacity. ${ }^{19}$ In line with these findings, adult murine VEGF (-/-) cells show a sharp depletion of the HSC pool: importantly, treatment with VEGF mutants revealed that activation of KDR is sufficient to rescue the HSC activity. ${ }^{20}$ Specifically, KDR favors self-renewal and survival of primitive hematopoietic cells. ${ }^{8,20,21}$

The functional role of KDR at more advanced stages of hematopoiesis is under investigation. KDR and VEGF are significantly expressed in megakaryocytic (MK) cells, suggesting that KDR may play a role in megakaryopoiesis. ${ }^{22,23}$ In a study performed on virtually pure MK-differentiating cells (MK unilineage cultures ${ }^{24}$ ), Casella et al. ${ }^{22}$ have recently shown that VEGF potentiates the maturation of MK precursors through the activation of Flt1; conversely, the effect of VEGF on the KDR receptor is not yet clarified. ${ }^{22}$ The 
co-expression of Flt1 and KDR in hematopoietic precursors renders difficult the investigation of the specific functional role, as compared to that of Flt1. ${ }^{8,10,11,20}$ Noteworthily, KDR also co-operates with Flt1 to promote not only HSC survival ${ }^{20}$ but also endothelial cell proliferation. ${ }^{25}$

The human TF1 cell line may represent a suitable model to study the specific effects of KDR on hematopoietic progenitors, without any interference by other VEGF receptors. Indeed, TF1 cells secrete VEGF and express KDR, but do not express Flt1. Furthermore, TF1 do not express Flt4 (VEGFR3), which is co-expressed with KDR in diverse leukemic cell types. ${ }^{11,26}$ It must also be noted that the TF1 cell line has been extensively utilized as a useful model to shed light into the mechanisms underlying the survival, proliferation and differentiation of normal HPCs. Indeed, TF1 cells share the phenotype of normal HPCs (i.e., they express CD34 and c-kit) and are granulocyte macrophage-colonystimulating factor (GM-CSF) dependent. ${ }^{27,28} \mathrm{TF} 1$ cells are also suitable to study erythro-MK differentiation, as they can massively differentiate into erythroid or MK lineage upon appropriate stimulation: a low rate of spontaneous MK differentiation can also be observed. ${ }^{27,28}$ In this study, we induced enforced expression of KDR in TF1 cell line to specifically study the effects of KDR stimulation on human early hematopoietic cells.

Our results originally show that in TF1 cells stimulation of exogenous KDR is sufficient to induce proliferative and survival signals. During the late stages of culture, VEGF treatment promotes MK differentiation, which is coupled with decreased proliferation, cell detachment and apoptosis induction. Preliminary results on human HPC cultures ${ }^{24}$ show that primary MK-differentiating cells secrete VEGF and express KDR, while the inhibition of KDR leads to a decrease of their differentiation.

\section{Results}

\section{Establishment of KDR-expressing TF1 cell clones (TF1-KDR)}

The phenotypic analysis of control cultures indicates that TF1 wt cells share the phenotype of erythro-MK progenitors. Moreover, a small fraction of cells are $\mathrm{CD} 61^{+}$and concomitantly show polylobated nuclei, indicating a spontaneous MK differentiation (Table 1). TF1 cells differentiate into erythroid or MK lineage upon appropriate stimulation: TF1 cells are therefore suitable for the study of erythro-MK differentiation. ${ }^{27,28}$ TF1 wt cells secrete significant amounts of VEGF in the culture medium (in a representative experiment, $170 \mathrm{pg} / \mathrm{ml} / 10^{5}$ cells of VEGF were detected in the cell culture supernatant) and express low levels of KDR protein and mRNA (Figure 1). Notably, TF1 wt cells do not express other VEGF receptors, such as Flt1 or Flt4, providing a useful tool to investigate the unique effects of KDR, independently of the other VEGF receptors (Figure 1a). To investigate how KDR affects hematopoietic proliferation and differentiation, we transduced the TF1 wt cell line with the vector encoding green fluorescence protein (GFP) alone or both KDR and GFP (Figure 1b); after transduction, both cell lines expressed high levels of GFP, thus showing that they had been efficiently
Table 1 TF1 wt cells express erythro-MK progenitor markers and undergo spontaneous MK differentiation

\begin{tabular}{lc}
\hline & Cells (\%) \\
\hline CD45 $^{+}$ & $97 \pm 2$ \\
CD34 $^{+}$ & $96 \pm 3$ \\
EpoR $^{+}$ & $20 \pm 8$ \\
GPA $^{+}$ & $94 \pm 5$ \\
CD41a $^{+}$ & $15 \pm 5$ \\
CD61 $^{+}$ & $8 \pm 3$ \\
CD42b $^{+}$ & $2 \pm 1$ \\
CD62p & \\
CD61 & polylobated \\
\hline
\end{tabular}

Analysis of CD expression and polylobated nuclei in TF1 wt control cultures. Mean \pm S.E.M. of four independent experiments is shown

transduced (data not shown). Cell lines were sorted for GFP or GFP-KDR, obtaining TF1-GFP and TF1-KDR bulk cell lines, respectively. Flow cytometry analysis showed that TF1-GFP cells barely express KDR, similarly to TF1 wt cells; on the other hand, high levels of KDR were detected in all TF1-KDR bulk cells (Figure 1c). However, GFP expression was stable in TF1-GFP cell line, while, upon KDR-GFP transduction, TF1KDR bulk cells underwent a progressive decrease in $\mathrm{KDR}^{+}$ cells $\left(\mathrm{KDR}^{+}\right.$cells $<50 \%$ after 30 rounds of duplications). In order to establish TF1-KDR cell lines stably expressing KDR, we performed limiting dilutions and obtained single cell clones. Finally, TF1-KDR clones expressed high and stable KDR levels (Figure 1c and d; data not shown), as confirmed at the mRNA level by RT-PCR (Figure 1d). TF1-KDR clones still secrete VEGF, though to a lesser extent than TF1 wt, TF1GFP or TF1-KDR bulk cells (Figure 1e). Flt1 and Flt4 proteins are not expressed in both TF1-KDR bulk and TF1-KDR clones (Figure 1f).

\section{GM-CSF starved TF1-KDR culture: KDR stimulation by exogenous VEGF induces cell growth and survival}

In the absence of GM-CSF, TF1 cells are quiescent and undergo apoptosis, ${ }^{29}$ thus providing a useful tool to study the effects of KDR stimulation on proliferation and survival. Thus, we combined GM-CSF withdrawal with VEGF treatment in TF1-KDR clone 4 cells, and monitored cell growth and viability. When cells are GM-CSF starved, VEGF treatment rescues cells from death and induces proliferation; the maximum effect was observed at $10 \mathrm{ng} / \mathrm{ml}$ (Figure $2 \mathrm{a}$ ). In the presence of $3-10 \mathrm{ng} / \mathrm{ml} \mathrm{VEGF,} \mathrm{cells}$ keep growing in culture for at least 20 passages, establishing a GM-CSF-independent but VEGF-dependent cell line. If these cells are VEGF starved, they stop growing and undergo apoptosis; however, if GM-CSF is re-added to the culture medium, cells can be completely rescued, thus showing that cells are still potentially GM-CSF dependent (data not shown).

To confirm that VEGF effects are due to exogenous KDR stimulation, we analyzed the viability and proliferation of TF1-KDR clones, TF1-KDR bulk, TF1 wt and TF1-GFP cells, 
a
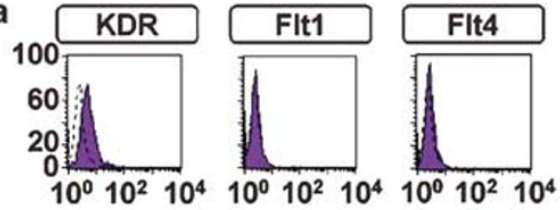

b

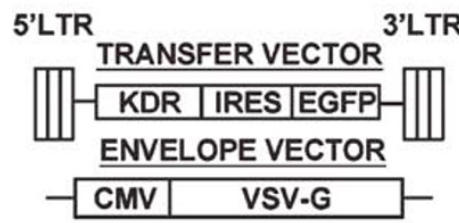

C

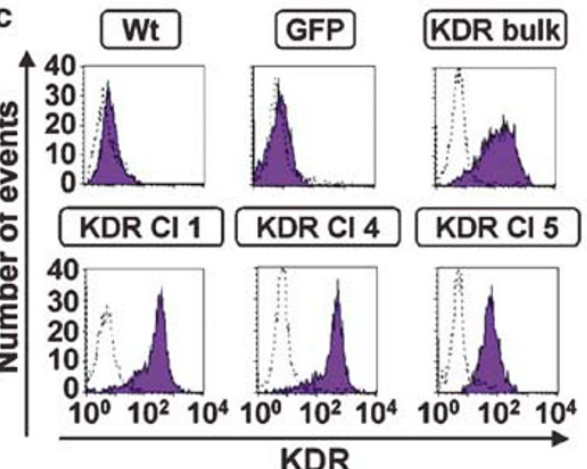

d

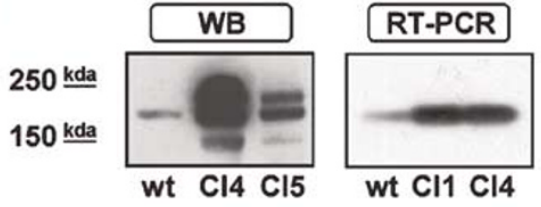

e

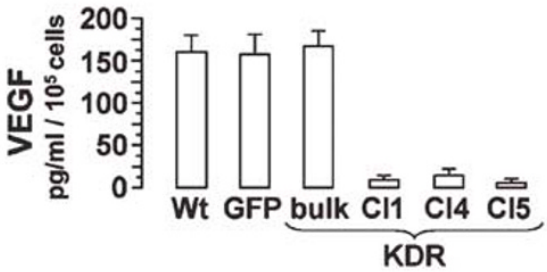

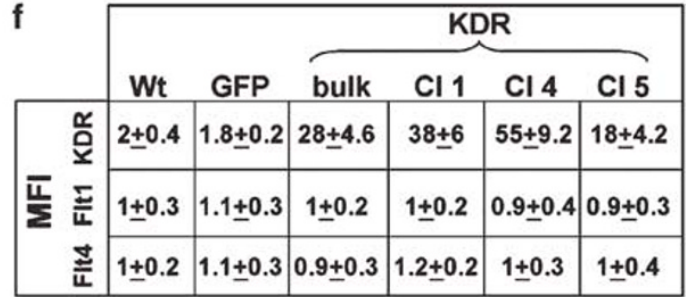

Figure 1 KDR gene transduction and expression in TF1 cells. (a) Flow cytometry analysis of VEGFRs in TF1 wt cells. Histograms with the dotted lines, isotype control. TF1 wt express KDR but do not express Flt1 or Flt4. One representative experiment out of four performed is shown. (b) PINCO-KDR-IRES-GFP vector. The transfer vector contains the full-length Moloney LTRs and a cassette composed of KDR-IRES-EGFP (enhanced GFP). The envelope vector contains the G glycoprotein of the vesicular stomatitis virus (VSV-G), to overcome the restricted host-cell range of the retroviral vector. VSV-G was under the control of the CMV. (c) Flow cytometry analysis of KDR in TF1 cells. TF1 wt, TF1-GFP, TF1-KDRbulk and TF1-KDR clones 1, 4 and 5 were analyzed for KDR expression 1 month after transduction. Histograms with the dotted lines, isotype control; filled histograms KDR antibody (KDR clone 1 - biotin). Virtually identical results were obtained by performing the analysis with the PE-conjugated KDR antibody (see Materials and Methods). One representative experiment of six performed is shown. (d) KDR expression in TF1 cells. Left panel: Western blot analysis of KDR in TF1 wt, TF1-KDR clone 4 and TF1-KDR clone 5 cells. Three main bands were detected in TF1-KDR clones. The 200 and $230 \mathrm{kDa}$ bands correspond to the KDR glycosylated forms. In TF1 wt, the $200 \mathrm{kDa}$ glycosylated form is clearly detected. One experiment of three performed is shown. Right panel: RTPCR analysis of KDR mRNA was analyzed in TF1 wt, TF1-KDR clone 1 and TF1-KDR clone 4. Notably, KDR mRNA was detected at low levels also in TF1 wt cells (one representative experiment of three is shown). (e) VEGF concentration in TF1 cell culture supernatants. TF1-KDR cell clones secrete very low amounts of VEGF. Mean \pm S.E.M. values from three independent experiments is shown. (f) Analysis of VEGFRs expression in TF1 cells. Values of the respective mean fluorescence fold increase $(\mathrm{MFI})$ are reported (fluorescence increase is calculated with respect to isotype control). The mean \pm S.E.M. from four independent experiments is shown

following VEGF treatment. In particular, we monitored the proliferative and antiapoptotic effects of VEGF $(10 \mathrm{ng} / \mathrm{ml})$ in the absence of GM-CSF (Figure 2b). The lack of effect of VEGF in TF1 wt and TF1-GFP confirms that VEGF acts by targeting the KDR receptor. In addition, similar effects were obtained in all TF1-KDR cell lines, independently of the TF1KDR cell line used, indicating that the effect of VEGF/KDR stimulation is not due to a clonal selection (Figure $2 b$ ). A further confirmation that VEGF affects viability and proliferation by binding to KDR is derived from the observation that the anti-KDR antibody $1 \mathrm{C} 11$ (which competes with VEGF for KDR binding ${ }^{30}$ ) is able to completely block VEGF action (Figure 2c). Furthermore, VEGF treatment was completely ineffective in the presence of the KDR inhibitor I, which is reported to specifically block the tyrosine-kinase activity of $\mathrm{KDR}^{31}$ (Figure 2c). Altogether, these results indicate that VEGF-mediated effects are due to its direct binding to KDR and to the stimulation of KDR signaling.

\section{GM-CSF-supplemented TF1-KDR culture: analysis of proliferation and apoptosis}

KDR stimulation by exogenous VEGF slightly increases proliferation and protects from apoptosis during early stages of culture

In the absence of GM-CSF, KDR stimulation concomitantly increases cell survival and growth. To uncouple the proliferative action from the antiapoptotic effect, we monitored cell growth and viability upon VEGF treatment in combination with GM-CSF. In TF1-KDR clone 4 stimulated by GM-CSF, cells are exponentially growing and perfectly viable; VEGF stimulation moderately but significantly increases cell growth within $24 \mathrm{~h}$, while viability is not increased (Figure 3a). This implies that VEGF stimulation has a direct effect on cell proliferation, independent of cell survival induction. Importantly, these findings are confirmed by the observation that, in the presence of GM-CSF, VEGF sharply increases the 


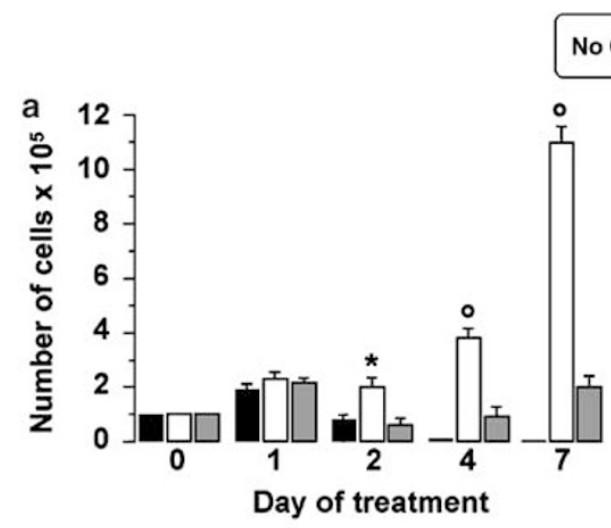

No GM-CSF
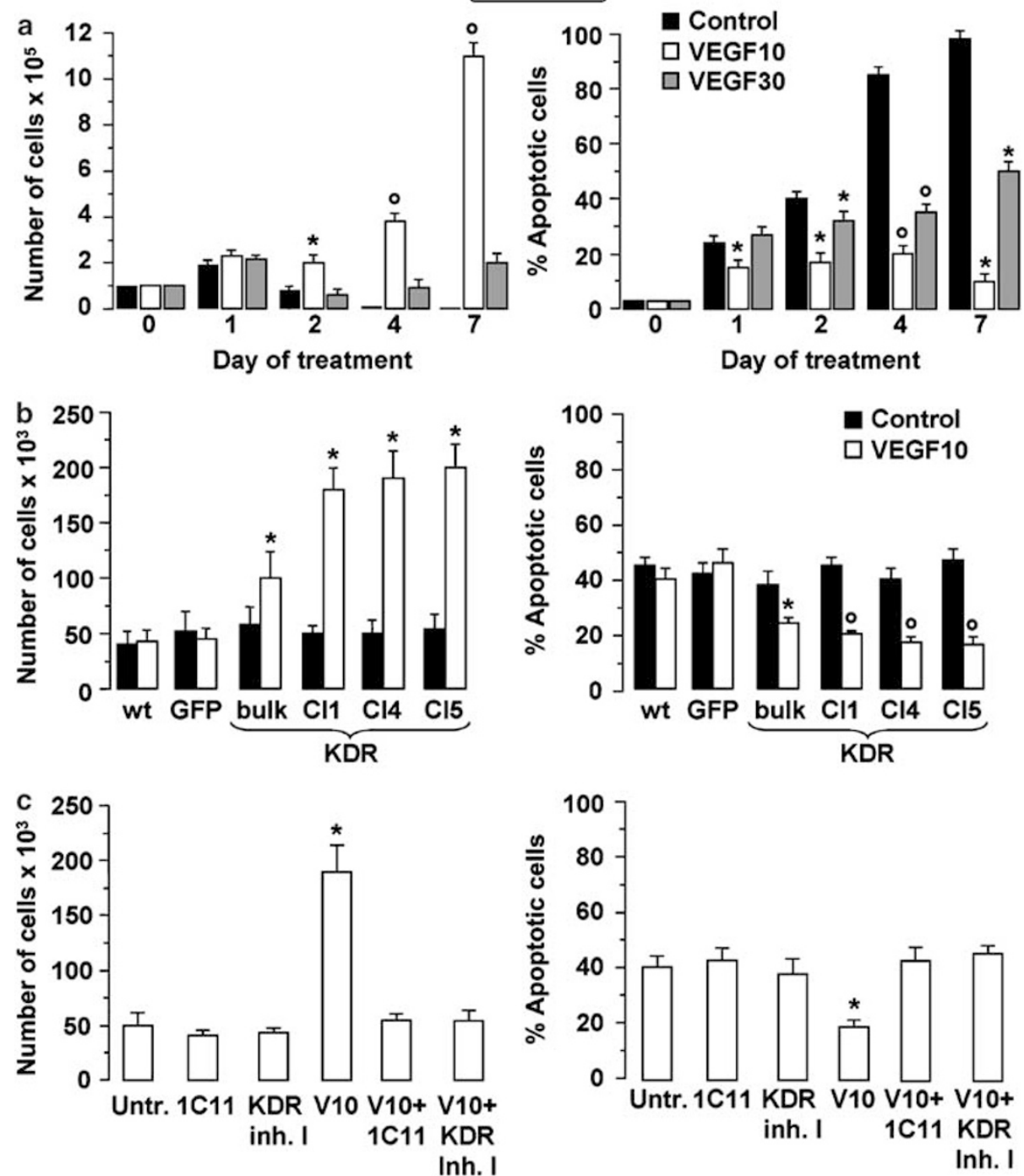

Figure 2 In GM-CSF starved TF1-KDR culture, VEGF stimulation induces proliferation and inhibition of apoptosis via KDR stimulation. (a) Cell growth (left panel) and apoptosis (right panel) in TF1-KDR clone 4 cells treated with VEGF 0,10 and $30 \mathrm{ng} / \mathrm{ml}$ for the indicated days, in the absence of GM-CSF in the culture medium Mean \pm S.E.M. from five independent experiments is shown. (b) Cell growth (left panel) and apoptosis (right panel) in GM-CSF starved TF1 cell lines treated with VEGF 0 (CONTROL) or VEGF $10 \mathrm{ng} / \mathrm{ml}$ for $48 \mathrm{~h}$. Cell number at $0 \mathrm{~h}$ was 100000 . Mean + S.E.M. from three independent experiments is shown. (c) Cell growth (left panel) and apoptosis (right panel) in GM-CSF-depleted TF1-KDR clone 4 cells, following $48 \mathrm{~h}$ of the indicated treatments $(\mathrm{V} 10=\mathrm{VEGF} 10 \mathrm{ng} / \mathrm{ml}$; Untr. $=$ Untreated; KDR inh $\mathrm{I}=\mathrm{KDR}$ inhibitor I). Cell number at $\mathrm{Oh}$ was 100000 . Mean + S.E.M. from three independent experiments is shown. ${ }^{*} P<0.05,{ }^{\circ} P<0.01$ in comparison with the respective control

numbers of mitotic cells (\% mitotic cells at $24 \mathrm{~h}$ : control $2 \pm 1 \%$ (mean \pm S.E.M.); VEGF $(10 \mathrm{ng} / \mathrm{ml}) 10 \pm 2 \%(P<0.01)$; VEGF $(30 \mathrm{ng} / \mathrm{ml}) 7 \pm 2 \%(P<0.05))$.

In TF1-KDR cells grown in the presence of GM-CSF, VEGF efficiently reduces the extent of apoptosis induced by the phorbol ester phorbol myristyl acetate (PMA) (20 nM), indicating that VEGF stimulation exerts an antiapoptotic effect independently of the apoptotic stimulus applied, that is, GM-CSF withdrawal or phorbol ester treatment. Notably, the protective effect was significant within $24 \mathrm{~h}$ from the beginning of the treatment (Figure $3 b$ ).
KDR stimulation hampers cell growth and elicits significant apoptosis during late stages of culture After $24 \mathrm{~h}$ of VEGF treatment in the presence of GM-CSF, cell growth does not further increase, but rather TF1-KDR clone 4 cells undergo growth reduction and enhanced apoptosis. Viability and cell growth are modulated in a dose-dependent mode, with a plateau reached at $30 \mathrm{ng} / \mathrm{ml}$ (Figure 4a; data not shown). Notably, at high concentrations (i.e. VEGF $\geq 30 \mathrm{ng} / \mathrm{ml}$ ), VEGF is strongly apoptogenic independently of the presence of GM-CSF (Figures 2a-4a). 


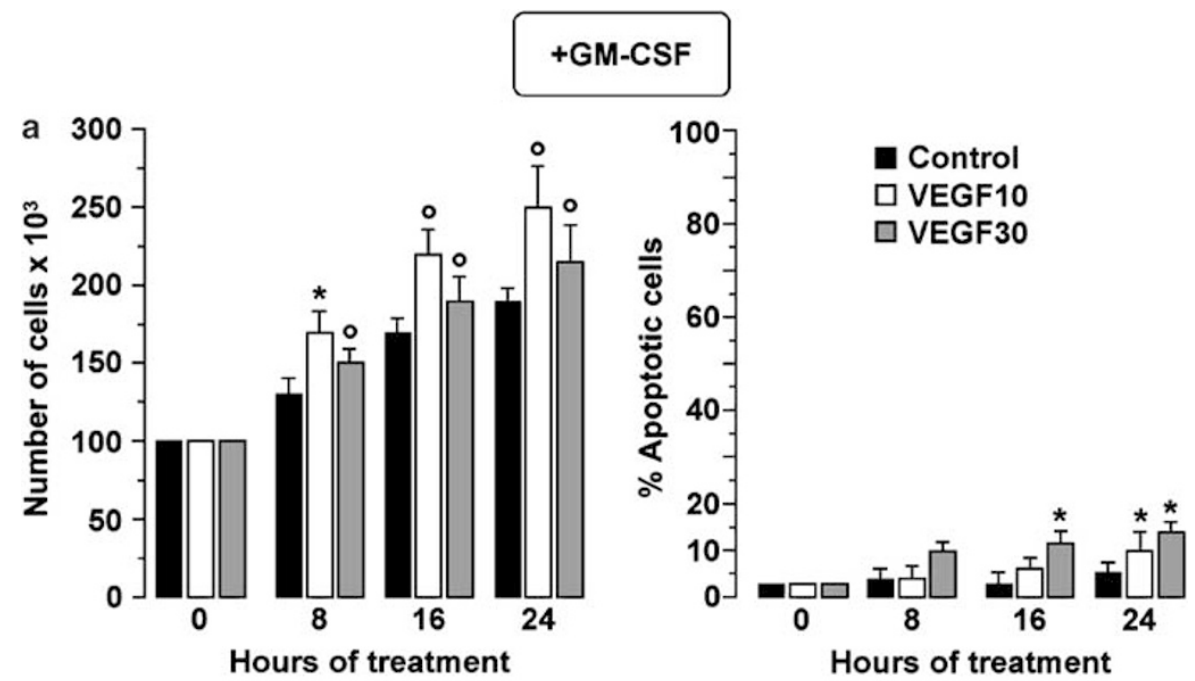

b

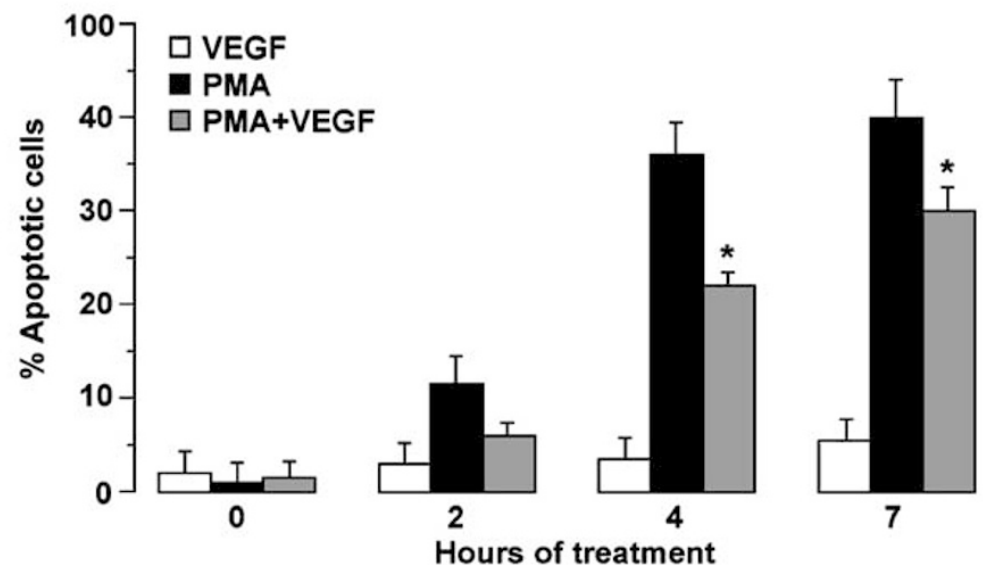

Figure 3 In GM-CSF-supplemented TF1-KDR culture, VEGF treatment increases proliferation and protects from apoptosis in the initial $24 \mathrm{~h}$ of culture. (a) Cell growth (left panel) and apoptosis (right panel) in TF1-KDR clone 4 cells treated with VEGF 0,10 and $30 \mathrm{ng} / \mathrm{ml}$ for the indicated hours, in the presence of GM-CSF in the culture medium. (b) VEGF (10 ng/ml) protects from PMA-induced apoptosis in TF1-KDR clone 4 cells in the presence of GM-CSF in the culture medium. Similar results were obtained with $30 \mathrm{ng} / \mathrm{ml}$ VEGF and in the absence of GM-CSF. Mean \pm S.E.M. values from four independent experiments are shown. ${ }^{*} P<0.05,{ }^{\circ} P<0.01 \mathrm{in}$ comparison to the respective control

VEGF stimulation decreases growth and induces apoptosis in different TF1-KDR cell clones, while it has no effect on TF1 cell lines lacking the exogenous KDR gene (Figure 4b). KDR inhibitors such as 1C11 antibody and KDR inhibitor I efficiently revert VEGF-mediated effects also in the presence of GMCSF (Figure 4c). Taken together, with the findings shown in Figure $2 b$ and $c$, these results indicate that the VEGFmediated effects are due to its direct binding to KDR and to the stimulation of KDR activity.

KDR-stimulated cells undergo adhesion, G0/G1 block and subsequently detach and undergo apoptosis

To clarify the events leading to growth decrease and apoptosis, we stimulated TF1-KDR clone 4 cells with 30 $\mathrm{ng} / \mathrm{ml}$ VEGF in the presence of GM-CSF and performed a detailed analysis of cell morphology, cell cycle and apoptosis. TF1 cells normally grow in suspension, but KDR stimulation resulted in a massive and rapid adhesion of the cells to the culture plate, even in the absence of a plate coating
(Figure 5a). In particular, cell adhesion increased with time: almost all the cells became adherent within $8 \mathrm{~h}$ of VEGF treatment. Notably, $4 \mathrm{~h}$ after the addition of VEGF, a substantial number of cells were adherent, whereas apoptosis was not observed. Subsequently, cell adhesion decreased, indicating that adherent cells detached from the culture plate. The onset of apoptosis was always concomitant with the decrease in adhesion, indicating a possible link between these two phenomena (Figure $5 \mathrm{~b}$ ). Cells did not become adherent following treatment with VEGF in the presence of KDR inhibitors (data not shown). Figure $5 \mathrm{c}$ shows cell cycle distribution of adherent and suspension cell fractions obtained following $48 \mathrm{~h}$ of VEGF treatment. Adherent cells are mostly in the $\mathrm{G} 0 / \mathrm{G} 1$ phase (40-50\% increase of $\mathrm{G} 0 / \mathrm{G} 1$ cells compared to those untreated), whereas a high proportion of apoptotic cells is only observed among suspension cells. Notably, the suspension fraction is also composed of the normally suspended growing cells, as well as by the adherent/detached cells. To understand whether apoptosis is related to detachment or rather occurs in nonadherent suspension cells, we 

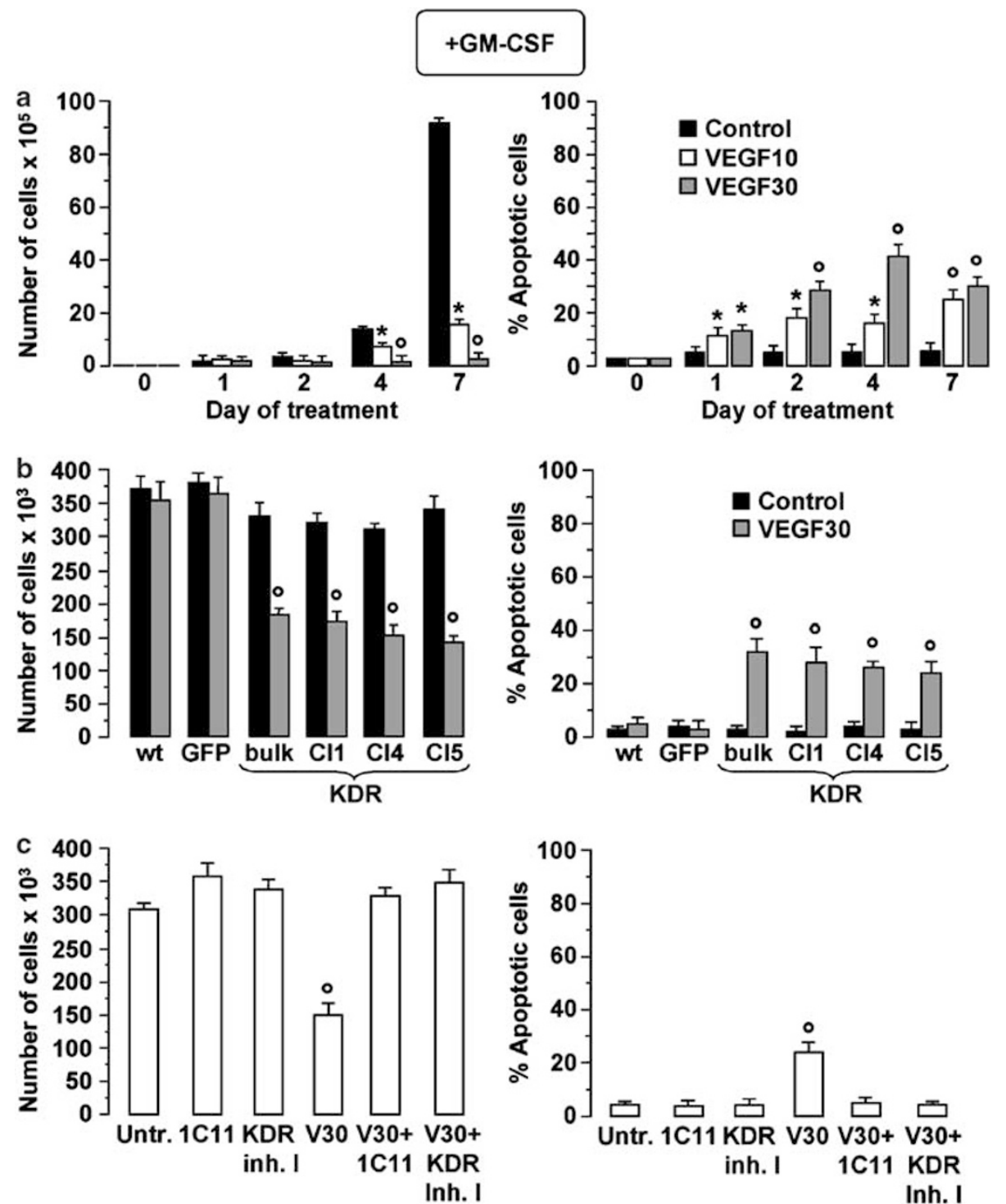

Figure 4 In GM-CSF-supplemented TF1-KDR culture, VEGF treatment decreases cell growth and induces apoptosis starting from $24 \mathrm{~h}$ of culture via KDR stimulation. Effect of VEGF on cell growth and apoptosis in the presence of GM-CSF in the indicated TF1 cell lines. (a) Cell growth (left panel) and apoptosis (right panel) in TF1-KDR clone 4 cells treated with VEGF 0,10 and $30 \mathrm{ng} / \mathrm{ml}$ for the indicated days, in the presence of GM-CSF in the culture medium. Mean $\pm S$.E.M. values from four independent experiments are shown. (b) Cell growth (left panel) and apoptosis (right panel) of TF1 cell lines following the addition of VEGF $30 \mathrm{ng} / \mathrm{ml}$ or VEGF 0 (CONTROL). The analysis was performed at culture day 2. In all, 100000 cells were seeded at day 0; mean \pm S.E.M. from four independent experiments is shown. (c) Cell growth (left panel) and apoptosis (right panel) of TF1-KDR clone 4 cells in the presence of GM-CSF after 2 days of the indicated treatments (Untr., untreated; V30, VEGF $30 \mathrm{ng} / \mathrm{ml}$, KDR inh. I, KDR inhibitor I). The analysis was performed at culture day 2. In all, 100000 cells were seeded at day 0; mean \pm S.E.M. values from three independent experiments are shown. ${ }^{*} P<0.05,{ }^{\circ} P<0.01$ in comparison to the respective control

performed an experiment to obtain adherent and virtually purified detached cells. In brief, $24 \mathrm{~h}$ after VEGF treatment, we discarded suspension cells from the supernatant by centrifugation and re-added the cell-free supernatant to adherent cells. After an additional $24 \mathrm{~h}$ ( $48 \mathrm{~h}$ VEGF treatment), as well as the adherent population, we also found floating cells, resulting from the detachment of some adherent cells. The analysis of apoptosis in the fractions of adherent and detached cells showed that only a minor fraction (20-30\%) of detached cells survived, whereas the remaining cells apoptosed (Figure $5 d$ ). Adherent cells did not show any signs of apoptosis, not even early events in the apoptotic execution such as caspase 3, 8 and 9 activation (Figure $5 d$ ). These results show that apoptosis execution occurs concomitantly with or immediately after the detachment of adherent, G0/G1 accumulated cells.

Apoptosis occurs via the Fas/Fas ligand pathway Several reports describe detachment-related apoptosis and G0/G1 arrest as processes related to the death pathway triggered by the Fas receptor (CD95) and its ligand 
a

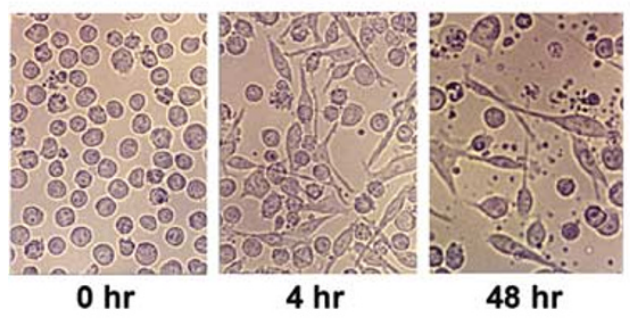

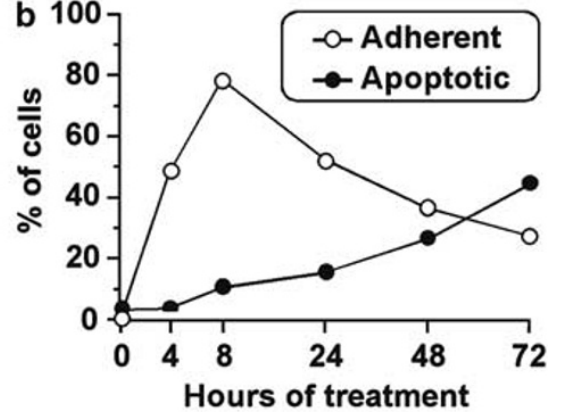

C
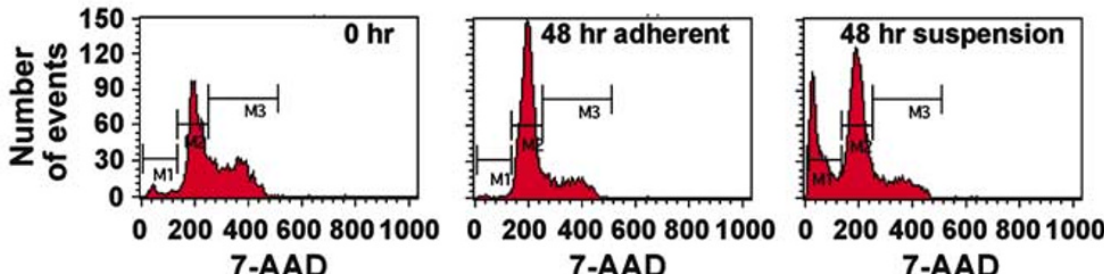

7-AAD 7-AAD

\begin{tabular}{|l|c|cc|}
\hline & \multirow{2}{*}{$0 \mathrm{hr}$} & \multicolumn{2}{|c|}{$48 \mathrm{hr}$} \\
$\%$ cells & & Adherent & Suspension \\
\hline pre-G0/G1 & 3 & 0.5 & 33 \\
G0/G1 & 56 & 81 & 53 \\
S-G2-M & 41 & 18.5 & 14 \\
\hline
\end{tabular}

d

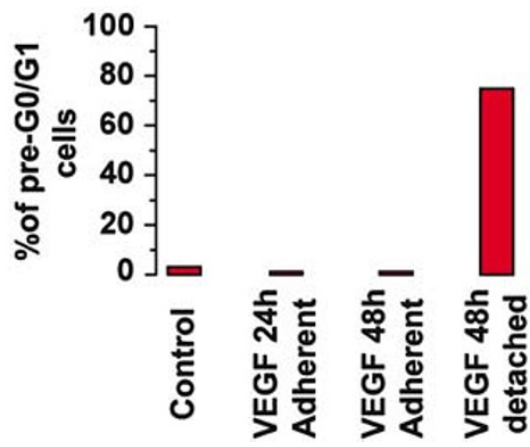

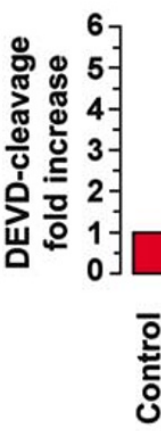

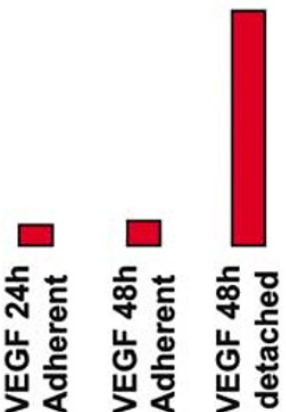

Figure 5 In GM-CSF-supplemented culture, VEGF stimulation induces cell adhesion, G0/G1 accumulation and detachment-related apoptosis. (a) Microscopy analysis of a representative TF1-KDR clone 4 cell population treated with $30 \mathrm{ng} / \mathrm{ml} \mathrm{VEGF}$ for the indicated hours (original magnification $\times 200$ ). (b) Adhesion and apoptosis induction after the indicated hours of $30 \mathrm{ng} / \mathrm{ml}$ VEGF treatment; a representative experiment of $n>10$ is shown. (c) Cell cycle analysis (flow cytometry profiles, top panels) and quantification (bottom panel) of TF1-KDR clone 4 cells after 0 or $48 \mathrm{~h}$ of VEGF treatment. At $48 \mathrm{~h}$, adherent and suspension cells were separately analyzed (M1, pre-G0/G1 phase; M2, G0/G1 phase; M3, S-G2-M phase). (d) Apoptosis analysis: pre-G0/G1 phase cells (left panel) and caspase 3 activity (DEVD-cleavage fold increase with respect to control cells, right panel) after $0 \mathrm{~h}$ (Control), 24 and $48 \mathrm{~h}$ of $30 \mathrm{ng} / \mathrm{ml} \mathrm{VEGF} \mathrm{treatment.} \mathrm{At} 48 \mathrm{~h}$, adherent and detached cells resulting from the $24 \mathrm{~h}$ adherent population were separately analyzed. A representative experiment out of four is presented here. Similar results were obtained with TF1-KDR clones 1 and 5

(Fas-L). ${ }^{32-36}$ Thus, we hypothesized that the mechanism leading to the death of adherent/detaching cells following KDR stimulation could be Fas-Fas- $L$ dependent. To explore this possibility, we quantified the expression of Fas and its ligand by immunofluorescence staining and FACS analysis. Control TF1-KDR cells do not express the death receptor and its ligand (TF1 wt or TF1-GFP do not express Fas or its ligand either, data not shown). However, a strong induction of expression is detected upon $48 \mathrm{~h}$ of VEGF treatment in the total cell population, as well as in both adherent and nonadherent fractions (Figure 6a; data not shown). To assess whether the induction of the expression of Fas and its ligand has a functional role in TF1-KDR-stimulated cells, we treated cells with both VEGF and inhibitors of the Fas-Fas-L death pathway: the pan-caspase inhibitor z-VAD-fmk, which blocks the executioners of Fas-induced apoptosis, and two different antibodies to Fas, which are able to block the receptor-ligand interaction (ZB4 and AB2 antibodies, respectively). All the inhibitors efficiently reduced VEGF-induced apoptosis in the total cell population by $50 \pm 12 \%$ (Figure $6 \mathrm{~b}$ ). These results show that the Fas-Fas- $L$ pathway activation is largely responsible for KDR-induced cell death, even though Fasindependent death pathways also seem to be involved in this phenomenon. Furthermore, the expression of Fas and its 
a
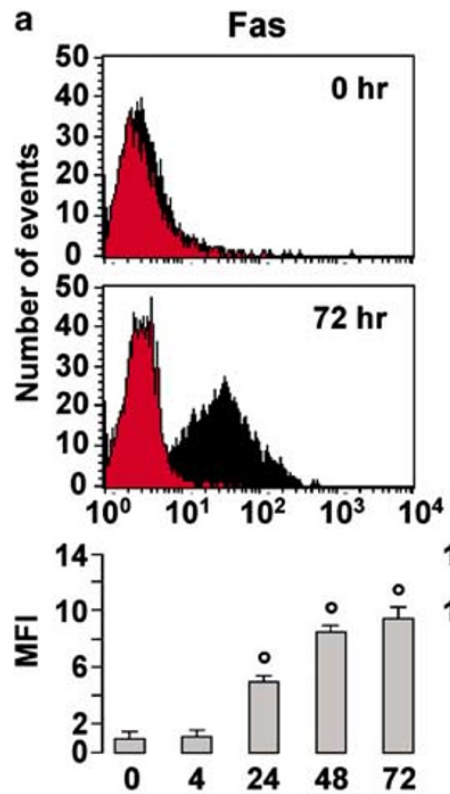

Hours of treatment
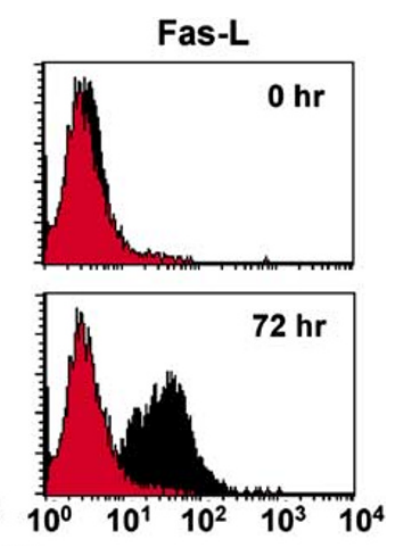

14

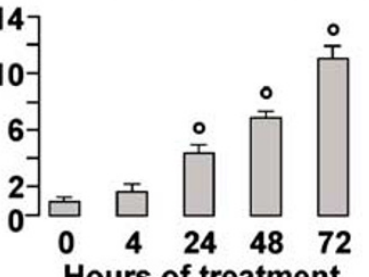

Hours of treatment

b

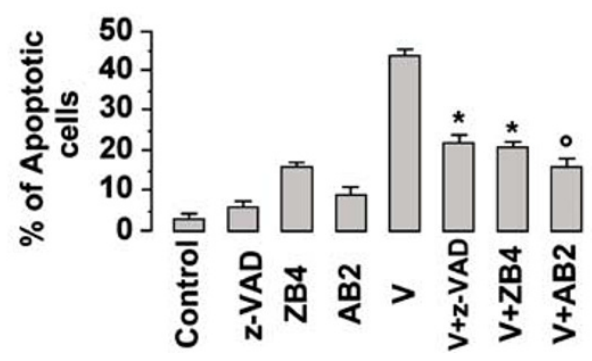

Figure 6 VEGF induces apoptosis via the Fas-Fas ligand pathway. (a) Flow cytometry analysis of Fas (left panels) and its ligand, Fas-L (right panels) at 0 and $72 \mathrm{~h}$ of $30 \mathrm{ng} / \mathrm{ml}$ VEGF treatment. The bottom histograms report the mean \pm S.E.M. values of the respective MFI of VEGF treatment with respect to MF of control cells $(0 \mathrm{~h})$; every MF was normalized with the isotype control. Mean \pm S.E.M. values of three experiments are shown here. (b) Effect of Fas pathway inhibitors on $30 \mathrm{ng} / \mathrm{ml}$ VEGF-induced cell death at $72 \mathrm{~h}$ of treatment $(V$, VEGF; z-VAD, z-VAD-fmk). Means \pm S.E.M. of three independent experiments are shown here. Similar results were obtained with TF1-KDR clones 1 and 5. ${ }^{*} P<0.05,{ }^{\circ} P<0.01$ in comparison with controls (a) and with VEGF (b)

ligand in the adherent fraction indicates that the cells may already be committed to apoptosis at this stage, though the execution of the apoptotic program occurs only after or concomitantly with detachment (Figure 5).

\section{In GM-CSF-supplemented or -deprived culture, VEGF-treated TF1-KDR cells undergo MK differentiation}

In GM-CSF-supplemented culture of TF1-KDR cells, KDR stimulation induces adhesion and accumulation in G0/G1 (Figure $5 \mathrm{a}-\mathrm{C}$ ), thus suggesting that these cells may be committed to a differentiation pathway. Flow cytometer analysis of the sorted adherent population showed that VEGF treatment induced a significant increase in the expression of adhesion proteins typically expressed during MK differentia-

tion (CD31, CD105, CD54, CD49e, CD62p) and of specific MK-differentiation markers (CD41a, CD61, CD42b). Consistently with the triggering of MK differentiation, we observed a decrease in the early progenitor marker CD34. Furthermore, the decrease in expression of specific erythroid proteins such as erythropoietin receptor and glycophorin A (EpoR and GPA) indicated the concomitant inhibition of the erythroid pathway of differentiation (Figure 7a and b). KDR-stimulated adherent cells showed signs of MK differentiation, also by morphological analysis. Indeed, as shown in Figure 7c, cells with polylobated nuclei appear following 48-72 h VEGF treatment.

These results clearly show that after $48 \mathrm{~h}$ of VEGF treatment, adherent cells are MK-differentiating cells, and that MK differentiation consistently follows adhesion. Notably, since apoptosis follows detachment of adherent cells (Figure 5), it also follows differentiation.

Flow cytometry analysis of detached versus adherent cells has shown that there is a general decrease of the adhesion molecules analyzed (i.e. CD31, CD41a, CD61, CD54, CD49e, CD62p, CD42b), suggesting that all of them are involved in detachment-related apoptosis (data not shown).

We further investigated the MK-differentiation process induced by VEGF, by analyzing the whole cell population (i.e., adherent plus suspension fractions). As observed by double labelling for CD61 and nuclei, polylobated cells are also CD61-expressing cells, thus showing a co-ordinated program of MK differentiation at the single-cell level, involving both induction of surface MK markers and DNA polyploidization (Figure 7d). The acquisition of the MK phenotype and the appearance of polylobated nuclei are dose-dependent, with a plateau at $30 \mathrm{ng} / \mathrm{ml}$.

Moreover, VEGF-induced differentiation was enhanced by co-treatment with either thrombopoietin (TPO) and/or PMA at nonapoptotic dosages, as shown by the increase in polylobated nuclei and CD61 + cells (Table 2). Notably, TPO and PMA treatments greatly potentiate the stimulatory effect of VEGF on MK maturation (Table 2).

GM-CSF deprived (Table 3) VEGF-treated cells similarly undergo MK differentiation as shown by enhanced expression of CD41a and induction of polylobated nuclei after 7 days of culture. MK marker-expressing cells similarly arrest in G0/G1 of the cell cycle. On the other hand, MK-differentiating cells appear after 2-4 days of culture, whereas, in the presence of GM-CSF, MK markers are already detected after 1 day of culture. Thus, KDR stimulation can induce differentiation independently of GM-CSF treatment, though, in the absence of GM-CSF, cells appear to be MK-committed later on during culture (data not shown).

\section{MK unilineage cultures: HPC-derived MK- differentiating cells secrete VEGF, express KDR and KDR blocking antibody $1 \mathrm{C11}$ reduces MK differentiation}

Our study on TF1KDR cells suggests that KDR may also be involved in normal megakaryopoiesis. To verify this hypothesis, we cultured HPCs in serum-free medium in the presence of TPO, thus obtaining MK unilineage cultures: ${ }^{24}$ MK-differentiating cells were then analyzed for specific 
markers, VEGF release and KDR expression. The increase of MK differentiation is coupled with an increase of VEGF release and KDR expression, suggesting a role for VEGF/ KDR in MK differentiation (Figure 8). Thus, we analyzed the effect of the KDR-blocking antibody 1C11 on MK differentiation. As evaluated by the significant decrease of polylobated nuclei and of the expression of membrane MK markers, the KDR inhibitor reduces MK differentiation (Figure 9), thus suggesting a crucial role for KDR also in human megakaryopoiesis.

\begin{tabular}{|c|c|c|c|}
\hline \multirow[t]{2}{*}{ a } & \multicolumn{2}{|c|}{$\%$ Positive Cells } & \multirow{2}{*}{ MFI } \\
\hline & $0 \mathrm{hr}$ & $48 \mathrm{hr}$ & \\
\hline CD45 & 99 & 98 & 1.0 \\
\hline CD34 & 98 & 88 & 0.2 \\
\hline CD11b & 85 & 15 & 0.3 \\
\hline CD31 & 99 & 100 & 3.6 \\
\hline CD105 & 100 & 100 & 2.0 \\
\hline CD54 & 100 & 100 & 3.8 \\
\hline CD49e & 98 & 99 & 3.6 \\
\hline GPA & 99 & 85 & 0.2 \\
\hline EpoR & 25 & 3 & 0.2 \\
\hline CD61 & 10 & 60 & 3.1 \\
\hline CD41a & 18 & 75 & 3.6 \\
\hline $\mathrm{CD} 42 \mathrm{~b}$ & 0 & 5 & $\begin{array}{c}1.2 \\
(* 10.0\end{array}$ \\
\hline CD62p & 4 & 74 & 9.0 \\
\hline
\end{tabular}
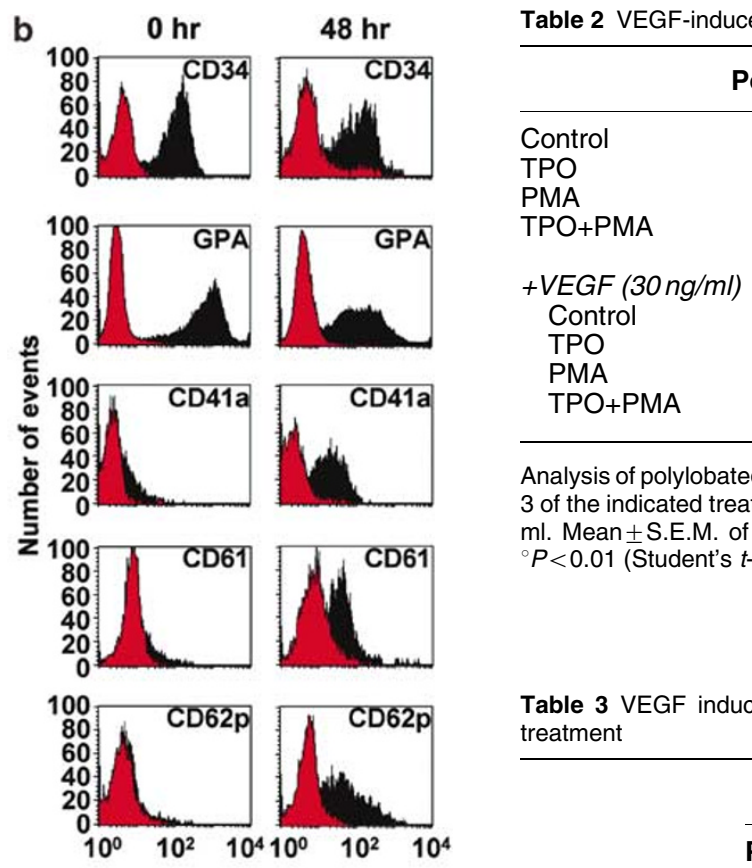

C

\section{$\mathbf{O ~ h r}$}

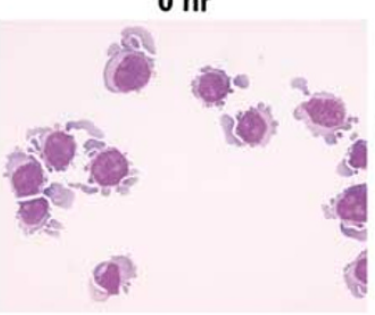

d
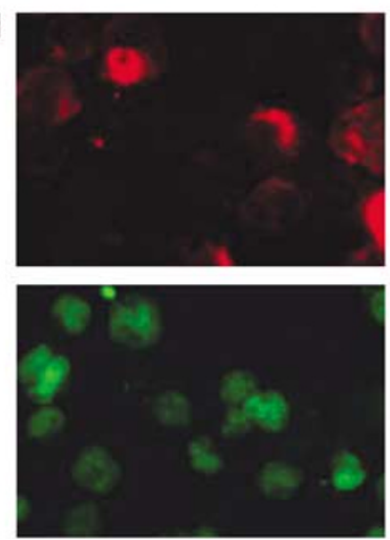
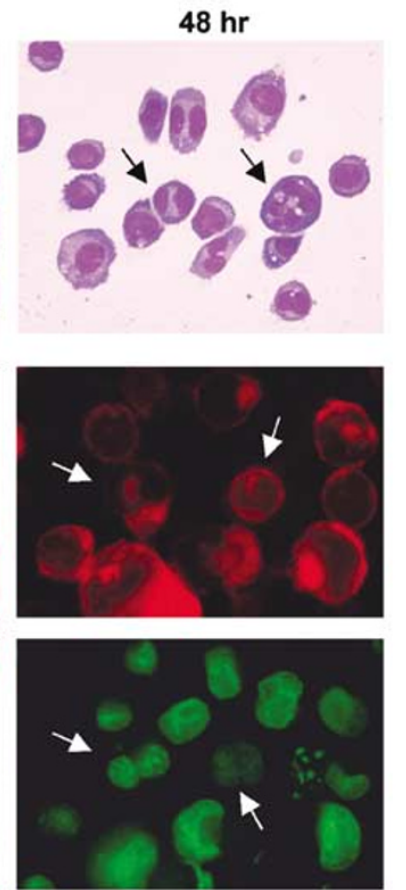

\section{Discussion}

KDR plays a key functional role in the proliferation and differentiation of endothelial cells, ${ }^{1}$ including the precursors. ${ }^{18}$ Conversely, its role in hematopoiesis has only been partly defined, ${ }^{7}$ particularly at the level of HPCs and subsequent stages of hematopoiesis.

As mentioned above, in view of the co-expression of VEGF and VEGF receptors in diverse types of hematopoietic cells, it is difficult to study the unique effects of KDR stimulation

Table 2 VEGF-induced Mk differentiation is enhanced by TPO and/or PMA

\begin{tabular}{lcc}
\hline & Polylobated nuclei cells (\%) & CD61+ cells (\%) \\
\hline Control & $3 \pm 1$ & $8 \pm 2$ \\
TPO & $5 \pm 1$ & $12 \pm 3$ \\
PMA & $4 \pm 1$ & $14 \pm 5$ \\
TPO+PMA & $9 \pm 2^{*}$ & $23 \pm 5^{*}$ \\
+ VEGF (30 $\mathrm{ng} / \mathrm{ml})$ & \\
Control & & \\
TPO & $10 \pm 2^{*}$ & $63 \pm 7$ \\
PMA & $16 \pm 3^{*}$ & $79 \pm 5^{*}$ \\
TPO+PMA & $24 \pm 5^{\star}$ & $89 \pm 6^{*}$ \\
\end{tabular}

Analysis of polylobated nuclei and CD61 expression in TF1 KDR cl4 cells at day 3 of the indicated treatments in the presence of GM-CSF. VEGF: VEGF $30 \mathrm{ng} /$ $\mathrm{ml}$. Mean \pm S.E.M. of four independent experiments is shown. ${ }^{\star} P<0.05$ and ${ }^{\circ} P<0.01$ (Student's $t$-test) compared to the respective control cultures

Table 3 VEGF induces Mk differentiation also in the absence of GM-CSF treatment

\begin{tabular}{lcc}
\hline & \multicolumn{2}{c}{- GM-CSF } \\
\cline { 2 - 3 } & Polylobated nuclei cells (\%) & CD41a+ cells (\%) \\
\hline Control & $3 \pm 1$ & $16 \pm 6$ \\
VEGF $(10 \mathrm{ng} / \mathrm{ml})$ & $10 \pm 3^{*}$ & $55 \pm 9^{\star}$ \\
\hline
\end{tabular}

Analysis of polylobated nuclei and CD41a expression in GM-CSF-deprived TF1 KDR cl 4 cells treated with $10 \mathrm{ng} / \mathrm{ml}$ VEGF for 7 days. Means \pm S.E.M. of three independent experiments are shown. ${ }^{\star} P<0.05$ compared to the control culture

Figure 7 Selective MK differentiation of VEGF-stimulated TF1-KDR cells. Analysis of differentiation on TF1-KDR clone 4 cells treated with $30 \mathrm{ng} / \mathrm{ml}$ VEGF for $0,48 \mathrm{~h}$ in the presence of GM-CSF. (a) Phenotypic analysis of the sorted adherent population. Percentage of positive cells was calculated with respect to the isotype control; mean fluorescence (MF) was normalized with the isotype control; MFI is the increase in MF of VEGF-treated cells at $48 \mathrm{~h}$ with respect to control cell MFs. * indicates MF fold increase of the positive cell subpopulation with repsect to the control cells. (b) Representative dot histograms of phenotypical analysis (isotype controls, red histograms; CD antibodies, black histograms). (c) Morphological analysis of the sorted adherent population. Black arrows point out some cells with polylobated nuclei after $48 \mathrm{~h}$ of VEGF treatment. Original magnification $\times 300$. (d) Immunofluorescence analysis of TF1-KDR clone 4 cells (adherent plus suspension cells) at 0 and $48 \mathrm{~h}$ of VEGF treatment. The cell immunopositivity for CD61 (top panels) is shown in red, the nuclei of the corresponding cells are colored in green in the bottom panels. White arrows at $48 \mathrm{~h}$ point out binucleated cells immunopositive for $\mathrm{CD} 61$. Original magnification $\times 600$. A representative experiment out of four is shown. Virtually identical results were obtained with other TF1-KDR clones 

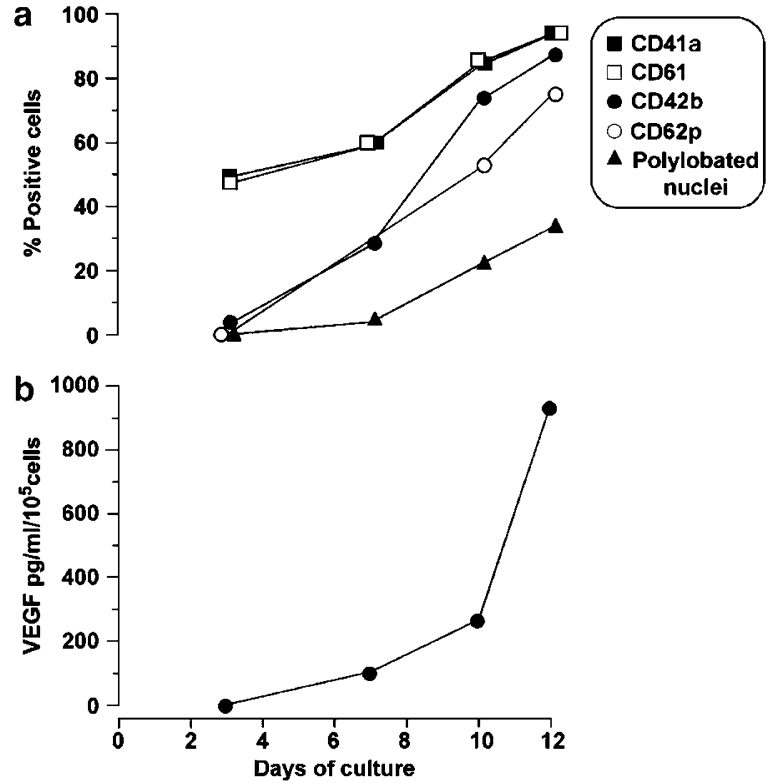

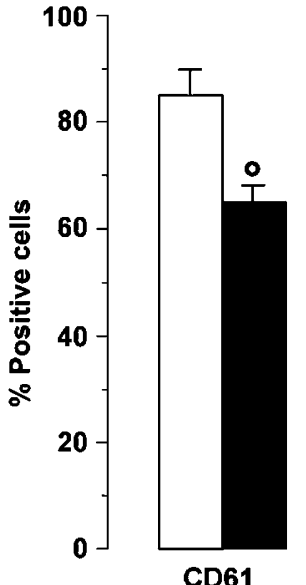

CD61
KDR
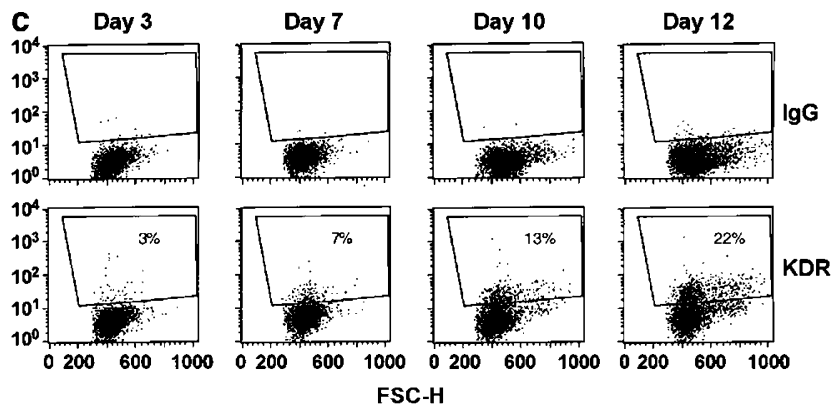

Figure 8 VEGF production and KDR expression in normal MK-differentiating cells. Analyses of MK differentiation, VEGF release and KDR expression in MK unilineage cultures. (a) Analysis of MK phenotype and of cells with polylobated nuclei; (b) VEGF concentration in culture supernatants; (c) flow cytometry analysis of KDR in normal MK-differentiating cells. Dot plots of the PE-conjugated KDR antibody stained cells (KDR) and the relative isotype controls (IgG) on the indicated days of culture. Percentage of KDR-positive cells was calculated with respect to the isotype control. One representative experiment out of four is presented here

without interference by other VEGF receptors, such as Flt1. To investigate the specific KDR effects on HPCs, we used the TF1 progenitor cell line, which expresses KDR but not Flt1 and Flt4. To enhance the effects of KDR stimulation, we established KDR-overexpressing TF1 cells, that is, TF1-KDR. In these cells, KDR stimulation initially induces antiapoptotic and proliferative stimuli. Thereafter, VEGF promotes differentiation along the MK pathway.

The specificity of VEGF action is indicated by several observations: (i) VEGF enhances survival, proliferation and differentiation in TF1-KDR, but not in TF1 wt or TF1-GFP cells; (ii) as mentioned above, TF1-KDR cells do not express any other VEGFRs, only KDR; (iii) a blocking anti-KDR antibody, as well as treatment with an inhibitor of KDR signalling, greatly inhibited the stimulatory effect of VEGF on TF1-KDR cells. The inhibitory effect of KDR blockers upon VEGF treatment also indicates that exogenous KDR is functional.

Figure 9 Reduced MK differentiation upon KDR inhibition in normal MKdifferentiating cells. Histograms of MK phenotype and of the percentage of cells with polylobated nuclei of MK unilineage cultures. Cells were incubated for 10 days with TPO in the absence or presence of KDR inhibitor $1 \mathrm{C} 11$ (control and 1 11, respectively). Means \pm S.E.M. of three independent experiments are shown here; ${ }^{*} P<0.05,{ }^{\circ} P<0.01$ in comparison to the respective control

KDR clearly drives HSC/HPC and leukemic progenitor cell growth: however, it is not elucidated whether KDR can trigger proliferation. In fact, KDR promotes both cell growth and survival, thus implying that the growth increase may be caused by its antiapoptotic effect. ${ }^{14,16,20}$ In the early phases of VEGF treatment in GM-CSF-supplemented cultures, we could uncouple the cell growth effect from the antiapoptotic action. In these conditions, KDR stimulation, while not exerting a survival effect, causes: (a) a slight, but significant increase of cell growth, and particularly (b) a sharp rise of mitotic figures. This indicates that KDR directly triggers cell proliferation. This cell proliferation phenomenon suggests that KDR may be implicated in proliferation of normal and neoplastic primitive hematopoietic cells. Subsequent to proliferation, KDR stimulation induces significant MK differentiation of TF1-KDR cells. Notably, VEGF stimulation is sufficient per se to induce MK differentiation, indicating a key role for KDR in megakaryopoiesis. Accordingly, TF1 cells spontaneously secrete VEGF and express KDR, and can undergo moderate MK differentiation ${ }^{22,27,28}$ (see also Figure 1, Tables 1-3). In particular, a moderate but significant proportion of untreated cells acquire the MK phenotype and show polylobated nuclei, indicating a spontaneous MK differentiation, possibly due to VEGF autocrine stimulation (Table 1). Moreover, we observed that KDR stimulation potentiates TPO and/or PMA-induced differentiation, thus suggesting that VEGF/KDR may act synergistically with other MK growth factors and their receptors to promote differentiation in normal megakaryocytes. Consistent with this model, normal MK-differentiating cells produce and secrete large amounts of VEGF, which act in co-operation with TPO to stimulate MK maturation ${ }^{22}$ (Figure 8). Most importantly, we observed that a subpopulation of MK-differentiating cells express KDR and that KDR inhibition decreases TPO-induced differentiation, thus indicating a crucial role for KDR in normal 
megakaryopoiesis. As suggested by the substantial inhibition of differentiation, the number of KDR-expressing cells may be higher than the quantity detected by flow cytometry: part of the positive population might not be bright enough for detection. In an attempt to detect these cells expressing low levels of KDR, our future experiments will focus on increasing the sensitivity of KDR immunofluorescence.

In TF1-KDR, the acquisition of an MK phenotype/morphology consistently follows a cell cycle arrest in G0/G1 and a transient phase of cell adhesion to the culture plate, indicating that the three processes are strictly related. This is in line with reports indicating that: (i) G1-S transition blockade is coupled with MK terminal differentiation and polyploidization; ${ }^{37,38}$ (ii) adhesion can occur concomitantly with MK differentiation upon appropriate stimulation in both MK cell lines ${ }^{39-41}$ and primary MK progenitors. ${ }^{42}$ Furthermore, adhesion of MK progenitors/precursors to bone marrow endothelial cells supports terminal MK differentiation and thrombopoiesis in the vascular niche. ${ }^{43}$ Altogether, these observations suggest that KDR-induced adhesion in TF1-KDR cells is a physiological process, possibly favoring MK differentiation and maturation: accordingly, in vivo MK differentiation may be promoted by cell adhesion via KDR.

At later stages of culture, VEGF stimulation induces apoptosis of the adherent MK-differentiating cells upon their detachment. The analysis of the apoptotic mechanism indicates that apoptosis occurs, at least in part, via the Fas/ Fas ligand pathway. In particular, cells may be committed to death by expressing the Fas/Fas ligand while they are still adherent, but they execute apoptosis by activating the death pathway only after detachment. Thus, loss of adherence may be considered as the discriminating event between the commitment and the execution phases of the apoptotic programme. Accordingly, the Fas-Fas-L-mediated signalling pathway was found to play a role in detachment-related apoptosis. $^{32,36}$ Possibly, as indicated by Aoudjit and Vuori, loss of cell adhesion would trigger Fas-mediated apoptosis by inducing the downregulation of the endogenous inhibitor of Fas-mediated signalling, Flip ${ }^{32}$ (see Grossmann ${ }^{36}$ for a review).

Growing evidence suggests that apoptosis may be a physiological part of the MK differentiation/maturation process. Two waves of apoptotic processes are apparently triggered during normal MK differentiation: (i) caspase activation limited to the cytoplasmic compartments is required for proplatelet formation; (ii) after proplatelet formation and platelet shedding, complete activation of the apoptotic machinery leads to apoptosis of senescent megakaryocytes. ${ }^{44,45}$ We further observed that in TF1-KDR cells VEGF induces MK differentiation and activates the Fas-Fas-L pathway; accordingly, in normal MK cells the Fas-Fas-L pathway increases proplatelet formation and production of functional platelets. ${ }^{44}$

Since exogenous KDR induces growth arrest and apoptosis upon VEGF treatment, it follows that TF1-KDR bulk cells (which secrete per se high amounts of VEGF) differentiate into MK cells (not shown) and eventually apoptose, whereas low VEGF-secreting TF1-KDR clones show stable KDR expression and long-lasting growth.

Independently of the differentiating stimulus used (e.g. phorbol esters and/or TPO and/or VEGF) TF1 tumor cell lines never reach complete differentiation/maturation. Indeed, TF1
MK-differentiating cells do not show the cytoplasmic von Willebrand factor expression or high nuclear lobation 27,28 (data not shown).

Overall, our data indicate that VEGF/KDR stimulation can affect hematopoietic cell fate in two sequential stages. In the first one, KDR stimulation induces proliferation and inhibits apoptosis in immature cells; in the second stage, cells undergo cell-cycle arrest, differentiate in MK cells, and undergo apoptosis upon detachment. These observations suggest that KDR may similarly exert a dual functional role in normal hematopoiesis. At early stages, KDR may mediate cell growth and self-renewal by increasing cell survival and proliferation; at later stages, KDR promotes MK differentiation and maturation, while triggering apoptotic-like mechanism(s) favoring the formation of proplatelets and production of platelets. Further studies on normal progenitor cells will be necessary to determine the specific functions played by KDR in megakaryopoiesis.

The KDR signalling pathway involved in the survival, proliferation and MK differentiation of hematopoietic cells is undetermined. Studies in endothelial cells have shown that phospholipase- $\mathrm{C}$ gamma/protein kinase-C/MAP-kinase is the main pathway of KDR signalling (reviewed in Shibuya ${ }^{46}$ ). Ongoing experiments aim to evaluate whether this mechanism is responsible for the VEGF-induced survival, proliferation and MK differentiation of TF1-KDR cells.

In conclusion, the TF1-KDR cell line provides a new, reliable tool to shed light on the effects of KDR activation in adult hematopoiesis, as well as in differentiating MK precursors. Specifically, this model may allow the clarification of the biochemical and molecular mechanisms underlying these effects, which cannot be readily analyzed in normal primitive hematopoiesis and megakaryopoiesis, in view of the paucity of available cells and low KDR expression levels.

\section{Materials and Methods}

\section{Cell lines: culture and treatments}

TF1 and the Phoenix ${ }^{47}$ cell lines were grown in RPMI 1640 and in high glucose-DMEM media, respectively. Media were supplemented with $10 \%$ FCS, $2 \mathrm{mM}$ L-glutamine and $10 \mathrm{U} / \mathrm{ml}$ penicillin/streptomycin (Sigma, St Louis, MO, USA).

Where appropriate, TF1 cells were treated with $5 \mathrm{ng} / \mathrm{ml}$ recombinant human (rh)-GM-CSF, $1-100 \mathrm{ng} / \mathrm{ml}$ rh-VEGF, $10 \mathrm{ng} / \mathrm{ml}$ rh-TPO (R\&D Systems, Minneapolis, MN, USA), $40 \mathrm{nM}$ z-VAD-fmk, $1 \mu \mathrm{M}$ mouse antihuman Fas blocking antibody (clone Ab-2), 100 nM VEGFR2 inhibitor I (KDR inh.l, Calbiochem-Novabiochem Gmbh, Schwalbach, Germany), $1 \mu \mathrm{M}$ Fas-blocking antibody (clone ZB4) issued by Upstate Biotechnology (Lake Placid, NY, USA), $1 \mu \mathrm{g} / \mathrm{ml} 1 \mathrm{C} 11$ anti-KDR-blocking antibody (supplied by ImClone Systems Incorporated, New York, NY, USA), PMA (Sigma $0.1-1 \mathrm{nM}$ to induce MKdifferentiation and $20 \mathrm{nM}$ to induce apoptosis). Adherent cells were detached from the culture plate upon incubation with nonenzymatic Cell Dissociation Solution (Sigma) and analyzed as indicated.

\section{HPC purification}

Adult peripheral blood was obtained from 20- to 40-year-old healthy male donors after informed consent. Low-density mononuclear cells were 
isolated by Ficoll-Hypaque density-gradient centrifugation and CD34 ${ }^{+}$ HPCs were then purified by MACS columns (Milteny, Bergisch, Gladbach, Germany) according to the manufacturer's instructions. Purified cells were more than $90 \% \mathrm{CD}^{+} 4^{+}$, as evaluated by flow cytometry analysis.

\section{MK unilineage cultures}

Purified HPCs were grown in serum-free unilineage MK liquid culture ${ }^{24}$ $\left(1 \times 10^{5} \mathrm{cells} / \mathrm{ml}\right.$, in the presence of a saturating dose of TPO $\left.(100 \mathrm{ng} / \mathrm{ml})\right)$ alone, or in combination with $1 \mu \mathrm{g} / \mathrm{ml} 1 \mathrm{C} 11$ anti-KDR-blocking antibody (IMClone Systems Incorporated). Cells were incubated in a fully humidified atmosphere of $5 \% \mathrm{CO}_{2}, 5 \% \mathrm{O}_{2}$ and $90 \% \mathrm{~N}_{2}$.

\section{Plasmids}

The PINCO-internal ribosomal entry site of encephalomyocarditis (IRES)GFP is a high-titer transfer vector containing the enhanced GFP marker gene. ${ }^{48}$ The vector is based on the Moloney retroviral vector. ${ }^{47}$ In brief, it contains the full-length Moloney long terminal repeats (LTRs), while the cytomegalovirus promoter (CMV)-GFP cassette CMV was substituted by IRES-GFP (by Clontech-BD, La Jolla, CA, USA). The IRES provides the most efficient means for co-expressing two genes from a single provirus. To obtain the PINCO-KDR-IRES-GFP transfer vector, KDR CDNA was subcloned (Xhol/EcoRI-blunt) into the PINCO-IRES-GFP vector, under the transcriptional control of $5^{\prime}$ LTR (see also Figure $1 \mathrm{~b}$ ). To overcome the restricted host-cell range of the retroviral vector, we used an envelope vector containing the G glycoprotein of vesicular stomatitis virus (VSV-G) under the control of the CMV.

\section{Virus production}

The expression system used to generate viral particles by transient transfection was composed of two plasmids: the envelope-coding plasmid VSV-G for pseudo-typing the virion with VSV-G, and the transfer vector plasmid PINCO-IRES-GFP or PINCO-KDR-IRES-GFP. Vector stocks were produced by calcium phosphate transient transfection, co-transfecting the two plasmids into the cell line Phoenix, as described in Grignani et $a .^{48}$.

\section{Transduction of TF1 cell line and cell cloning}

For infection, cells were plated with the viral supernatant supplemented with $4 \mu \mathrm{g} / \mathrm{ml}$ polybrene $\left(5.0 \times 10^{4}\right.$ cells $/ \mathrm{ml}$ viral supernatant $)$ and then centrifuged directly in the plate (Beckman GS-6KR centrifuge), for $45 \mathrm{~min}$ at $1800 \mathrm{rpm}, 32^{\circ} \mathrm{C}$; after centrifugation, cells were incubated for $75 \mathrm{~min}$ in $5 \% \mathrm{CO}_{2}$ at $32^{\circ} \mathrm{C}$. Cells were exposed to two infection cycles consecutively. Then, they were washed twice with cold PBS and fresh medium was added. At $48 \mathrm{~h}$ after the infection, transduced cells were analyzed for GPF and KDR expression using a flow cytometer with a FACSCan, Becton Dickinson (BD, La Jolla, CA, USA); GFP-KDR double-positive cells were sorted with a FACSVANTAGE cell sorter (BD). Sorted cells (TF1-KDR bulk) were cloned by limiting dilution cultures ( 0.25 cells/well) in a 96 -well plate.

\section{Analysis of adhesion, proliferation and viability}

The fraction of adherent cells was quantified by counting adherent cells among the total cell population directly in culture dishes, using a contrastphase microscope. Cell proliferation and viability were quantified by manual counting. Cell viability was detected by the exclusion of the Trypan
Blue dye ( $5 \mu \mathrm{g} / \mathrm{ml}$ in PBS; Sigma). Cell growth was also quantified by the cell growth determination kit MTT according to the procedure indicated by the manufacturer (Sigma).

\section{Morphological analysis: polylobated nuclei}

Cells were collected, washed in PBS, cytocentrifuged on glass slides and identified by morphological analysis after staining with May-GrunwaldGiemsa (Sigma). The number of polylobated nuclei cells were calculated by counting at least 600 cells in at least 10 randomly chosen fields.

\section{Cell cycle and mitotic cell analysis}

Cells were fixed in $70 \%$ cold ethanol for $1 \mathrm{~h}$, washed in PBS and stained for $1 \mathrm{~h}$ at $4^{\circ} \mathrm{C}$ with $3 \mu \mathrm{g} / \mathrm{ml}$ of the DNA-intercalating agent 7-aminoactinomycin D (7-AAD, Sigma). For mitotic cell detection, 7-AAD-stained cells were labelled for $30 \mathrm{~min}$ at $4^{\circ} \mathrm{C}$ with $3 \mu \mathrm{g} / \mathrm{ml}$ of monoclonal antibody against mitosis-specific phosphoepitopes MPM2 ${ }^{49}$ (Upstate Biotechnology), washed, incubated with anti-mouse IgG1-cyanine3 antibody (Caltag Laboratories, Burlingame, CA, USA) and washed three times. Cells were then analyzed for fluorescence intensity using a flow cytometer and MODFIT software (Verity Software House, Topsham, ME,) to eliminate cell doublets.

\section{Apoptosis}

Apoptosis was detected and quantified by multiparametric analysis using the following apoptotic parameters. Nuclear fragmentation: Cell nuclei were stained by adding the vital nuclear dye Hoechst $33342(5 \mu \mathrm{g} / \mathrm{ml}$, SIGMA) directly to the culture medium. Cells were then monitored for nuclear fragmentation using a fluorescence microscope. The fraction of cells with fragmented nuclei among the total cell population was calculated by counting at least 200 cells in at least six random selected fields, as described in Ghibelli et al. ${ }^{50}$ DNA analysis: Apoptotic cells show a hypodiploid DNA content upon ethanol fixation. Thus, nonviable cells can be detected as pre-G0/G1 cells upon cell cycle analysis using a flow cytometer. Caspase activity assay. Caspase 3, 8 and 9 activities were assayed by quantifying the cleavage of colorimetric caspase substrates (respectively, DEVDp-nitroanaline, IETDp-nitroanaline, LEHDp-nitroanaline), following the procedure recommended by the manufacturer ( $R \& D$ Systems).

In the figures, unless otherwise indicated, apoptosis was quantified by nuclear fragmentation analysis.

\section{Enzyme-linked immunosorbent assay}

VEGF concentration in the cell culture supernatants was measured using human immunoassays (R\&D System) specific for the soluble isoform VEGF-A165. A sensitivity of $5 \mathrm{pg} / \mathrm{ml}$ could be achieved.

\section{Flow-cytometric analysis}

Monoclonal antibodies were purchased from B-D, except for biotinylated anti-KDR monoclonal antibody (clone 1-Sigma, biotinylated by Hoelzel Diagnostika, Cologne, Germany), anti-Fas ligand (Calbiochem), and the phycoerythrinated (PE) anti-KDR, anti-Flt1 and anti-Flt4 antibodies (R\&D Systems). In brief, cells were washed and incubated for $30 \mathrm{~min}$ on ice in the dark with a PE or purified/biotinylated antibody (3-5 $\mu \mathrm{g} / \mathrm{ml})$. The cells were then re-incubated with a secondary goat anti-mouse-PE or with PE-streptavidin (Molecular Probes, Eugene, OR, USA). Cells were then 
washed and analyzed on a FACSCan (BD). Nonviable cells were excluded by $30 \mathrm{ng} / \mathrm{ml}$ 7-AAD addition immediately before analysis.

\section{Immunofluorescence analysis}

Cells were fixed for 10 min with $4 \%$ paraformaldehyde, washed in $0.2 \%$ BSA in PBS spotted on a glass slide and air dried. After permeabilization ( $5 \mathrm{~min}, 0.2 \%$ Triton $\mathrm{X}-100$ ), cells were incubated overnight at $4^{\circ} \mathrm{C}$ with $3 \mu \mathrm{g} / \mathrm{ml}$ mouse IgG1-anti-human CD61 primary antibody or an equal amount of isotype control (DAKO, Glostrup, Denmark). Then, cells were washed, incubated for $1 \mathrm{~h}$ at room temperature with $1 \mu \mathrm{g} / \mathrm{ml}$ anti-mouse IgG1-Cyanine3 antibody (Caltag Laboratories) and washed again. Slides were mounted on a glass coverslip with $100 \mathrm{nM}$ Sytox-Green nuclear dye (Molecular Probes) and analyzed. No labelling was detected in isotype controls.

\section{Reverse transcriptase (RT)-PCR}

Total RNA was extracted from 2-5 $\times 10000$ cells using the $\mathrm{CsCl}$ gradient technique in the presence of $12 \mu \mathrm{g} / \mathrm{ml}$ Escherichia coli rRNA as a carrier. RT was performed according to the manufacturer's instructions (Boheringer Manheim, Germany) and normalized for beta2-microglobulin (20 PCR cycles). To evaluate KDR gene expression, aliquots of RT-RNA were amplified by $15-30$ cycles of PCR, blotted onto nylon membranes and hybridized with a specific probe. The following synthetic oligonucleotides were used: KDR forward: caccagaaatgtaccagacc reverse: ggaggaggagga probe: taatgctcagcaggatggcaaagac.

\section{Statistical analysis}

The significance of the differences in mean values was determined by using the Student's $t$-test. $P<0.05$ was considered significant.

\section{KDR Western blot analysis}

KDR analysis was performed on total cell lysates from 100000 cells, according to the procedure described in Casella et al. ${ }^{22}$ The mouse monoclonal, clone A-3, was used as an anti-KDR antibody (Santa Cruz Biotechnology).

\section{Acknowledgements}

This work was supported in part by NIH grant 1R01HL63168 to CP. We thank IMCLONE for supplying the IMC-1C11-neutralizing anti-KDR antibody. We thank Dr. R Guerriero for her critical review of the manuscript and helpful comments. We thank Dr. V Lulli, Dr. S Santoro and Dr. C Conticello for help with VEGFRs expression analysis, M Fontana, Dr. S Hourshid, M Blasi for editorial assistance and A Zito for the graphics.

\section{References}

1. Ferrara N (2001) Role of vascular endothelial growth factor in regulation of physiological angiogenesis. Am. J. Physiol. Cell Physiol. 280: 1358-1366

2. Karkkainen MJ and Petrova TV (2000) Vascular endothelial growth factor receptors in the regulation of angiogenesis and lymphangiogenesis. Oncogene 19: 5598-5605

3. Ferrara $\mathrm{N}$ and Gerber HP (2001) The role of vascular endothelial growth factor in angiogenesis. Acta Haematol. 106: 148-156
4. Gerber HP, McMurtrey A, Kowalski J, Yan M, Keyt BA, Dixit V and Ferrara N (1998) Vascular endothelial growth factor regulates endothelial cell survival through the phosphatidylinositol $3^{\prime}$-kinase/Akt signal transduction pathway. Requirement for Flk-1/KDR activation. J. Biol. Chem. 273: 30336-30343

5. Shalaby F, Ho J, Stanford WL, Fischer KD, Schuh AC, Schwartz L, Bernstein A and Rossant J (1997) A requirement for Flk1 in primitive and definitive hematopoiesis and vasculogenesis. Cell 89: 981-990

6. Shalaby F, Rossant J, Yamaguchi TP, Gertsenstein M, Wu XF, Breitman ML and Schuh AC (1995) Failure of blood-island formation and vasculogenesis in Flk-1-deficient mice. Nature 376: 62-66

7. Gerber HP and Ferrara N (2003) The role of VEGF in normal and neoplastic hematopoiesis. J. Mol. Med. 81: 20-31

8. Cerdan C, Rouleau A and Bhatia M (2004) VEGF-A165 augments erythropoietic development from human embryonic stem cells. Blood 103: 2504-2512

9. Padro T, Bieker R, Ruiz S, Steins M, Retzlaff S, Burger H, Buchner T, Kessler T, Herrera F, Kienast J, Muller-Tidow C, Serve H, Berdel WE and Mesters RM (2002) Overexpression of vascular endothelial growth factor (VEGF) and its cellular receptor KDR (VEGFR-2) in the bone marrow of patients with acute myeloid leukemia. Leukemia 16: 1302-1310

10. Bellamy WT, Richter L, Frutiger Y and Grogan TM (2001) Expression of vascular endothelial growth factor and its receptors in hematopoietic malignancies. Cancer Res. 59: 728-733

11. Bairey O, Boycov O, Kaganovsky E, Zimra Y, Shaklai M and Rabizadeh E (2004) All three receptors for vascular endothelial growth factor (VEGF) are expressed on B-chronic lymphocytic leukemia (CLL) cells. Leuk. Res. 28: 243-248

12. El-Obeid A, Sunnuqrut N, Hussain A, Al-Hussein K, Gutierrez Ml and Bhatia K (2004) Immature B cell malignancies synthesize VEGF, VEGFR-1 (Flt1) and VEGFR-2 (KDR). Leuk. Res. 28: 133-137

13. Verstovsek S, Estey E, Manshouri T, Giles FJ, Cortes J, Beran M, Rogers A, Keating M, Kantarjian $\mathrm{H}$ and Albitar M (2002) Clinical relevance of vascular endothelial growth factor receptors 1 and 2 in acute myeloid leukaemia and myelodysplastic syndrome. Br. J. Haematol. 118: 151-156

14. Dias S, Hattori K, Zhu Z, Heissig B, Choy M, Lane W, Wu Y, Chadburn A, Hyjek E, Gill M, Hicklin DJ, Witte L, Moore MA and Rafii S (2000) Autocrine stimulation of VEGFR-2 activates human leukemic cell growth and migration. J. Clin. Invest. 106: 511-521

15. Katoh O, Tauchi H, Kawaishi K, Kimura A and Satow $Y$ (1995) Expression of the vascular endothelial growth factor (VEGF) receptor gene, KDR, in hematopoietic cells and inhibitory effect of VEGF on apoptotic cell death caused by ionizing radiation. Cancer Res. 55: 5687-5692

16. Santos SC and Dias S (2004) Internal and external autocrine VEGF/KDR loops regulate survival of subsets of acute leukemia through distinct signaling pathways. Blood 103: 3883-3889

17. Ziegler BL, Valtieri M, Porada GA, De Maria R, Muller R, Masella B, Gabbianelli M, Casella I, Pelosi E, Bock T, Zanjani ED and Peschle C (1999) KDR receptor: a key marker defining hematopoietic stem cells. Science 285: 1553-1558

18. Peichev M, Naiyer AJ, Pereira D, Zhu Z, Lane WJ, Williams M, Oz MC, Hicklin DJ, Witte L, Moore MA and Rafii S (2000) Expression of VEGFR-2 and AC133 by circulating human $\mathrm{CD} 34(+)$ cells identifies a population of functional endothelial precursors. Blood 95: 952-958

19. Pelosi E, Valtieri M, Coppola S, Botta R, Gabbianelli M, Lulli V, Marziali G, Masella B, Muller R, Sgadari C, Testa U, Bonanno G and Peschle C (2002) Identification of the hemangioblast in postnatal life. Blood 100: 3203-3208

20. Gerber HP, Malik AK, Solar GP, Sherman D, Liang XH, Meng G, Hong K, Marsters JC and Ferrara N (2002) VEGF regulates haematopoietic stem cell survival by an internal autocrine loop mechanism. Nature 417: 954-958

21. Larrivee B, Lane DR, Pollet I, Olive PL, Humphries RK and Karsan A (2003) Vascular endothelial growth factor receptor-2 induces survival of hematopoietic progenitor cells. J. Biol. Chem. 278: 22006-22013

22. Casella I, Feccia T, Chelucci C, Samoggia P, Castelli G, Guerriero R, Parolini I, Petrucci E, Pelosi E, Morsilli O, Gabbianelli M, Testa U and Peschle C (2003) Autocrine-paracrine VEGF loops potentiate the maturation of megakaryocytic precursors through Flt1 receptor. Blood 101: 1316-1323

23. Selheim F, Holmsen $H$ and Vassbotn FS (2002) Identification of functional VEGF receptors on human platelets. FEBS Lett. 512: 107-110 
24. Guerriero R, Testa U, Gabbianelli M, Mattia G, Montesoro E, Macioce G, Pace A, Ziegler B, Hassan HJ and Peschle C (1995) Unilineage megakaryocytic proliferation and differentiation of purified hematopoietic progenitors in serumfree liquid culture. Blood 15: 3725-3736

25. Autiero M, Waltenberger J, Communi D, Kranz A, Moons L, Lambrechts D, Kroll J, Plaisance S, De Mol M, Bono F, Kliche S, Fellbrich G, Ballmer-Hofer K, Maglione D, Mayr-Beyrle U, Dewerchin M, Dombrowski S, Stanimirovic D, Van Hummelen P, Dehio C, Hicklin DJ, Persico G. Herbert JM, Communi D, Shibuya M, Collen D, Conway EM and Carmeliet P (2003) Role of PIGF in the intra- and intermolecular cross talk between the VEGF receptors Flt1 and Flk1. Nat. Med. 9: 936-943

26. Fielder W, Graeven U, Ergun S, Verago S, Kilic N, Stockschlader M and Hossfeld DK (1997) Expression of FLT-4 and its ligand VEGF-C in acute myeloid leukemia. Leukemia 11: 1234-1237

27. Murate T, Saga S, Hotta T, Asano H, Ito T, Kato K, Tsushita K, Kinoshita T, Ichikawa A, Yoshida S and Saito H (1993) The close relationship between DNA replication and the selection of differentiation lineages of human erythroleukemia cell lines K562, HEL, and TF1 into either erythroid or megakaryocytic lineages. Exp. Cell Res. 208: 35-43

28. Testa U, Grignani F, Hassan HJ, Rogaia D, Masciulli R, Gelmetti V, Guerriero R, Macioce G, Liberatore C, Barberi T, Mariani G, Pelicci PG and Peschle C (1998) Terminal megakaryocytic differentiation of TF-1 cells is induced by phorbol esters and thrombopoietin and is blocked by expression of PML/ RARalpha fusion protein. Leukemia 12: 563-570

29. Apati A, Janossy J, Brozik A, Bauer P and Magocsi M (2003) Calcium induces cell survival and proliferation through the activation of the MAPK pathway in a human hormone-dependent leukemia cell line, TF-1. J. Biol. Chem. 278: 9235-9243

30. Hunt S (2001) Technology evaluation: IMC-1C11, ImClone Systems. Curr. Opin. Mol. Ther. 3: 418-424

31. Sun L, Tran N, Tang F, App H, Hirth P, McMahon G and Tang C (1998) Synthesis and biological evaluations of 3-substituted indolin-2ones: a novel class of tyrosine kinase inhibitors that exhibit selectivity toward particular receptor tyrosine kinases. J. Med. Chem. 41: 25882603

32. Aoudjit F and Vuori K (2001) Matrix attachment regulates Fas-induced apoptosis in endothelial cells: a role for $\mathrm{C}$-flip and implications for anoikis. J. Cell Biol. 152: 633-643

33. Beletskaya IV, Nikonova LV and Beletsky IP (1997) Cell cycle specificity of Fas-mediated apoptosis in WIL-2 cells. FEBS Lett. 412: 91-93

34. Yang Y, Mercep M, Ware CF and Ashwell JD (1995) Fas and activationinduced Fas ligand mediate apoptosis of $T$ cell hybridomas: inhibition of Fas ligand expression by retinoic acid and glucocorticoids. J. Exp. Med. 181: 1673-1682

35. Jedema I, Barge RM, Willemze R and Falkenburg JH (2003) High susceptibility of human leukemic cells to Fas-induced apoptosis is restricted to G1 phase of the cell cycle and can be increased by interferon treatment. Leukemia 17: 576-584

36. Grossmann J (2002) Molecular mechanisms of 'detachment-induced apoptosis - Anoikis'. Apoptosis 7: 247-260
37. Kikuchi J, Furukawa Y, Iwase S, Terui Y, Nakamura M, Kitagawa S, Kitagawa M, Komatsu N and Miura Y (1997) Polyploidization and functional maturation are two distinct processes during megakaryocytic differentiation: involvement of cyclin-dependent kinase inhibitor p21 in polyploidization. Blood 89: 3980-3990

38. Baccini V, Roy L, Vitrat N, Chagraoui H, Sabri S, Le Couedic JP, Debili N, Wendling F and Vainchenker W (2001) Role of p21(Cip1/Waf1) in cell-cycle exit of endomitotic megakaryocytes. Blood 98: 3274-3282

39. Jiang F, Jia Y and Cohen I (2002) Fibronectin- and protein kinase C-mediated activation of ERK/MAPK are essential for proplateletlike formation. Blood 99: 3579-3584

40. Tseng CP, Huang $\mathrm{CL}$, Huang $\mathrm{CH}$, Cheng JC, Stern A, Tseng $\mathrm{CH}$ and Chiu DT (2003) Disabled-2 small interfering RNA modulates cellular adhesive function and MAPK activity during megakaryocytic differentiation of K562 cells. FEBS Lett. 541: 21-27

41. Mizutani $C$, Tohyama $Y$, Miura $Y$, Hishita $T$, Nishihara $T$, Yamamura $H$, Ichiyama S, Uchiyama T and Tohyama K (2002) Sustained activation of MEK1ERK1/2 pathway in membrane skeleton occurs dependently on cell adhesion in megakaryocytic differentiation. Biochem. Biophys. Res. Commun. 297: 664-671

42. Zweegman S, Veenhof MA, Huijgens PC, Schuurhuis GJ and Drager AM (2000) Regulation of megakaryocytopoiesis in an in vitro stroma model: preferential adhesion of megakaryocytic progenitors and subsequent inhibition of maturation. Exp. Hematol. 28: 401-410

43. Avecilla ST, Hattori K, Heissig B, Tejada R, Liao F, Shido K, Jin DK, Dias S, Zhang F, Hartman TE, Hackett NR, Crystal RG, Witte L, Hicklin DJ, Bohlen P, Eaton D, Lyden D, de Sauvage F and Rafii S (2004) Chemokine-mediated interaction of hematopoietic progenitors with the bone marrow vascular niche is required for thrombopoiesis. Nat. Med. 10: 64-71

44. De Botton S, Sabri S, Daugas E, Zermati Y, Guidotti JE, Hermine O, Kroemer $G$, Vainchenker W and Debili N (2002) Platelet formation is the consequence of caspase activation within megakaryocytes. Blood 100: 1310-1317

45. Clarke MC, Savill J, Jones DB, Noble BS and Brown SB (2003) Compartmentalized megakaryocyte death generates functional platelets committed to caspase-independent death. J. Cell Biol. 160: 577-587

46. Shibuya M (2003) Vascular endothelial growth factor receptor-2: its unique signaling and specific ligand, VEGF-E. Cancer Sci. 94: 751-756

47. Kinsella TM and Nolan GP (1996) Episomal vectors rapidly and stably produce high-titer recombinant retrovirus. Hum. Gene Ther. 7: 1405-1413

48. Grignani $F$, Kinsella $T$, Mencarelli $A$, Valtieri $M$, Riganelli $D$, Grignani $F$ Lanfrancone L, Peschle C, Nolan GP and Pelicci PG (1998) High-efficiency gene transfer and selection of human hematopoietic progenitor cells with a hybrid EBV/retroviral vector expressing the green fluorescence protein. Cancer Res. 58: 14-19

49. Westendorf JM, Rao PN and Gerace L (1994) Cloning of cDNAs for M-phase phosphoproteins recognized by the MPM2 monoclonal antibody and determination of the phosphorylated epitope. Proc. Natl. Acad. Sci. USA 91: 714-718

50. Ghibelli L, Fanelli C, Rotilio G, Lafavia E, Coppola S, Colussi C, Civitareale P and Ciriolo MR (1998) Rescue of cells from apoptosis by inhibition of active GSH extrusion. FASEB J. 12: 479-486 